\title{
ANTIBACTERIAL ACTIVITY OF COMPLEX OF ENROFLOXACIN WITH NANOPOLYMER GLULA-DPG-PEG600
}

\author{
B. O. Chekh', I. A. Dron ${ }^{2}$, S. I. Vynnytska ${ }^{2}$, V. V. Oleksa ${ }^{2}$, I. E. Atamaniuk ${ }^{3}$, V. V. Vlizlo ${ }^{1}$ \\ bogdanchekh@gmail.com
}

${ }^{1}$ Institute of Animal Biology NAAS,

38 Vasyl Stus str., Lviv 79034, Ukraine

${ }^{2}$ National University "Lviv Polytechnic",

12 Bandery str., Lviv 79013, Ukraine

${ }^{3}$ State Scientific-Research Control Institute

of Veterinary Medicinal Products and Feed Additives,

11 Donetska str., Lviv 79019, Ukraine

This article presents the results of the study of antibacterial activity of complex of enrofloxacin with nanopolymer based on pseudo-polyamino acids GluLa-DPG-PEG600. Nanopolymer GluLa-DPG-PEG600 has low toxicity to mammalian cells and white laboratory rats, and has an ability to bind blood serum albumins which is important characteristics of nanopolymer as drug transporter.

Antibacterial activity was investigated used the method of serial dilutions which was prepared on microbial cells of Pseudomonas aeruginosa incubated at $37^{\circ} \mathrm{C}$ for 44 hours. After 22 and 44 hours of incubation we calculated the density of microbial cells suspension. The results of the study have shown that the complex of enrofloxacin with GluLa-DPG-PEG600 has higher antibacterial activity that enrofloxacin (control). The minimum inhibitory concentration (MIC) of complex after 22 hours of incubation was $3.12 \mu \mathrm{g} / \mathrm{ml}$ and was lower that control group $(6.25 \mu \mathrm{g} / \mathrm{ml})$. However, after 44 hours of incubation MIC of the complex of enrofloxacin with GluLa-DPG-PEG600 was $6.25 \mu \mathrm{g} / \mathrm{ml}$ and was the same as MIC of enrofloxacin. Higher antibacterial activity of the complex of enrofloxacin with GluLa-DPG-PEG600 compared with the control is probably due to the presence of polyethylene glycol and lauric acid in GluLa-DPG-PEG600 molecule which can acts as membrane permabilizers and particularly PEG can enhance antibiotic affinity to DNA that probably increase its antibacterial activity.

Obtained results show positive prospects for using nanopolymer GluLa-DPG-PEG600 as antibiotic transporter, particularly enrofloxacin which belong to fluoroquinolones class of antibiotics.

Keywords: NANOPOLYMERS, PSEUDO-POLYAMINO ACIDS, ANTIBIOTICS, ENROFLOXACIN, MICROBIAL CELLS, ANTIBACTERIAL ACTIVITY

\section{АНТИБАКТЕРІАЛЬНА АКТИВНІСТЬ АНТИБІОТИКА ЕНРОФЛОКСАЦИНУ 3 НАНОПОЛІМЕРОМ GLULA-DPG-PEG600}

\author{
Б. О. Чех , І. А. Дронь , С. І. Винницька², В. В. Олекса, I. С. Атаманюк', В. В. Влізло \\ bogdanchekh@gmail.com
}

${ }^{1}$ Інститут біології тварин НААН, вул. В. Стуса, 38, м. Львів, 79034, Україна, ${ }^{2}$ Національний університет «Львівська політехніка», вул. С. Бандери, 12, м. Львів, 79013, Україна ${ }^{3}$ Державний науково-дослідний контрольний інститут ветеринарних препаратів та кормових добавок, вул. Донецька, 11, м. Львів, 79019, Україна

У статті подано результати дослідження антибактеріальної активності антибіотика енрофлоксацину та енрофлоксачину у комплексі з нанополімером GluLa-DPG-PEG600 на основі псевдополіамінокислот. Нанополімер GluLa-DPG-PEG600, згідно з результатами попередніх досліджень, є нетоксичним щчодо клітин ссавиів і організму шурів та здатний зв язуватись з альбумінами крові, щчо є ваюлливю характеристикою його як транспортера діючих речовин ліків. 
Антибактеріальна активність була досліджена відносно мікробних клітин Pseudomonas aeruginosa методом серійних розведень за інкубаиії дослідних проб за $37{ }^{\circ} \mathrm{C}$ протягом 44 годин. Кількість мікробних клітин реєстрували за допомогою приладу для визначення густини бактеріальної суспензї̈ після 22 та 44 годин інкубаиії. Результати дослідження показали, що вищу антибактеріальну активність серед досліджуваних сполук проявляе антибіотик у комплексі з GluLa-DPG-PEG600, мінімальна інгібуюча концентращія (MIK) якого була нижчою від контрольної і після 22 годин інкубачії становила 3,12 мкг/мл, після 44 годин інкубаиї6,25 мкг/мл і була на рівні контрольної. Вища антибактеріальна активність енрофлоксацину з полімером GluLa-DPG-PEG600 порівняно з контролем, ймовірно, зумовлена наявністю поліетиленгліколю та, можливо, лауринової кислоти у складі молекули нанополімеру GluLa-DPG-PEG600. Так, завдяки наявності в молекулі нанополімеру GluLa-DPG-PEG600 поліетиленгліколю та лауринової кислоти він здатний збільшувати проникність мембрани бактерійних клітин. Також поліетиленгліколь у складі нанополімеру ймовірно збільшує спорідненість енрофлоксащину до ДНК, підсилюючи ичим його антибактеріальну активність.

Отримані дані свідчать про перспективу використання нанополімеру GluLa-DPG-PEG600 як носія антибіотиків, зокрема енрофлоксаџину, щьо належить до антибіотиків класу фторхінолонів.

Ключові слова: НАНОПОЛІМЕРИ, ПСЕВДОПОЛІАМІНОКИСЛОТИ, АНТИБІОТИКИ, ЕНРОФЛОКСАЦИН, МІКРОБНІ КЛІТИНИ, АНТИБАКТЕРІАЛЬНА АКТИВНІСТЬ

\title{
АНТИБАКТЕРИАЛЬНАЯ АКТИВНОСТЬ АНТИБИОТИКА ЭНРОФЛОКСАЦИНА С НАНОПОЛИМЕРОМ GLULA-DPG-PEG600
}

\author{
Б. А. Чех , И. А. Дронь ${ }^{2}$, С. И. Винницька², В. В. Олекса ${ }^{2}$, И. Е. Атаманюк, В. В. Влизло \\ bogdanchekh@gmail.com
}

${ }^{1}$ Институт биологии животных НААН, ул. В. Стуса, 38, г. Львов, 79034, Украина

${ }^{2}$ Национальний университет «Львовская политехника», ул. С. Бандеры, 12, г. Львов, 79013, Украина

${ }^{3}$ Державний научно-исследовательский контрольный институт ветеринарных препаратов и кормовых добавок, ул. Донецкая, 11, г. Львов, 79019, Украина

В статье представлены результаты исследования антибактериальной активности антибиотика энрофлоксацина и энрофлоксацина в в комплексе с нанополимером на основе псевдополиаминокислот GluLa-DPG-PEG600. Нанополимер GluLa-DPG-PEG600, согласно результатам предыдуциих исследований, является нетоксичным относительно клеток млекопитающих и организма крыс и способен связываться с альбумины крови, что является важной характеристикой его как транспортера действующих веществ лекарственных препаратов.

Антибактериальная активность была исследована относительно микробных клеток Рsеиdотоnas aеruginosa методом серийных разведений при инкубачии проб при $37^{\circ} \mathrm{C}$ в течение 44 часов. Количество микробных клеток регистрировали с помощью прибора для определения мутности бактериальной суспензии после 22 и 44 часов инкубации. Результаты исследования показали, что выше антибактериальной активностью обладает антибиотик в комплексе с GluLa-DPG-PEG600, минимальная ингибирующая конщентрация (МИК) которого была ниже контрольной и после 22 часов инкубаџии составляла 3,12 мкг/мл, после 44 часов инкубаиии - 6,25 мкг/мл и была на уровне контрольной. Высшая антибактериальная активность энрофлоксацина с полимером GluLa-DPG-PEG600 по сравнению с контролем, вероятно, обусловлена наличием полиэтиленгликоля и, возможно, лауриновой кислоты в составе молекуль нанополимера GluLa-DPG-PEG600. Так, благодаря наличию в молекуле нанополимера GluLa-DPGPEG600 полиэтиленгликоля и лауриновой кислоть он способен увеличивать проницаемость мембраны бактериальных клеток. Также полиэтиленгликоль в составе нанополимера вероятно увеличивает сродство энрофлоксащину к ДНК, таким образом усиливая его антибактериальную активность.

Полученные данные свидетельствуют о перспективе использования нанополимера GluLa-DPGPEG600 как транспортера антибиотиков, в частности энрофлоксаџина, который принадлежсит к антибиотикам класса фторхинолонов.

КлючевЫе слова: НАНОПОЛИМЕРЫ, ПСЕВДОПОЛИАМИНОКИСЛОТЫ, АНТИБИОТИКИ, ЭНРОФЛОКСАЦИН, МИКРОБНЫЕ КЛЕТКИ, АНТИБАКТЕРИАЛЬНАЯ АКТИВНОСТЬ 
Nowadays, one of the main task for pharmacy is development a novel polymeric compounds for drug delivery and other biomedical purposes $[6,8]$. Among of the compounds which capable of binding and transporting various substances to mammals organs and tissues, pseudo-polyamino acids which have similar chemical structure to polypeptides, but do not contain peptide bonds should be promising drug delivery systems [1].

Pseudo-polyamino acids based nanocarriers contains $\mathrm{N}$-derivatives of glutamic acids, polyolxyethelene and polyoxypropylene diols are promising drug delivery systems that do not cause side effects in optimal concentrations.

Nanopolymer GluLa-DPG-PEG600 has low toxicity investigated on bovine sperm cells and white laboratory rats (Rattus norvegicus var. Alba, Wistar line) $[3,5]$.

Nanopolymer can also bind to blood albumins and be transported to rat organs and tissues [4]. The main purpose of our work was to research the antibacterial activity of enrofloxacin in complex with nanopolymer GluLa-DPG-PEG600.

\section{Materials and methods}

For this study we synthesized polymer GluLa-DPG-PEG600 which consist of glutamic and lauric acids (GluLa) (Sigma-Aldrich ${ }^{\circledR}$ ), dipropylene glycol (DPF) (Sigma-Aldrich ${ }^{\circledR}$ ), and polyethylene glycol 600 (PEG600) (Sigma-Aldrich $^{\circledR}$ ) (fig.).

Synthesis of polymer was conducted through interaction of diol and N-protected glutamic acid and polyoxyethylene (at different ratios of reagents) in a solution of benzene. The solution was cooled to $280 \mathrm{~K}$, while stirring adding the appropriate amount of 4-dimethylaminopyridine (DMAP) and dicyclohexylcarbodiimide (DCK). The reaction mixture was incubated at $288 \mathrm{~K}$ for 3 and then $3 \mathrm{~h}$ at $308 \mathrm{~K}$. Dicyclohexylurea (DCC) was separated by filtration, and the polymer solution was evaporated. For purification of polyesters from catalyst residues and DCK, their solutions in benzene were prepared, washed three times with $15 \% \mathrm{NaCl}$ solution in $0.1 \mathrm{~N} \mathrm{HCl}$ and $15 \%$ aqueous $\mathrm{NaCl}$ solution to neutral $\mathrm{pH}$, after that it was dried over the magnesium sulfate, then filtered and evaporated [10].
To study the antibiotic activity of complex of enrofloxacin with GluLa-DPG-PEG600, it was made $1 \%$ dispersion solution of this complex where enrofloxacin content $=0,16 \%$.

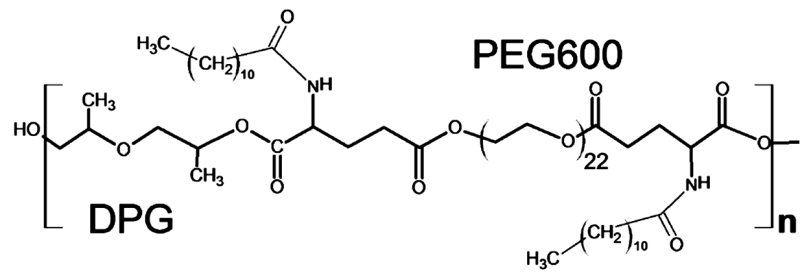

$n=6-15$

GluLa

Fig. Structure of GluLa-DPG-PEG600

Antibacterial activity was investigated used the method of serial dilutions which was prepared on microbial cells of Pseudomonas aeruginosa, where enrofloxacin and the complex of enrofloxacin with GluLa-DPG-PEG600 were diluted with distilled water into a series of solutions in which concentration of enrofloxacin was: $50 \mu \mathrm{g} / \mathrm{ml}, 25 \mu \mathrm{g} / \mathrm{ml}$, $12.5 \mu \mathrm{g} / \mathrm{ml}, 6.25 \mu \mathrm{g} / \mathrm{ml}, 3.12 \mu \mathrm{g} / \mathrm{ml}, 1.56 \mu \mathrm{g} / \mathrm{ml}$, $0.78 \mu \mathrm{g} / \mathrm{ml}, 0.39 \mu \mathrm{g} / \mathrm{ml}$ and $0.19 \mu \mathrm{g} / \mathrm{ml}$ [7]. Pure enrofloxacin was a control in experiment. The culture of Pseudomonas aeruginosa cells was added to each solution, after that infected solutions were incubated for 44 hours at $37{ }^{\circ} \mathrm{C}$. After 22 and 44 hours of incubation, the amount of bacterial cells in each solution were calculated in Macfarland units (1 MF = 300,000,000 microbial cells) using device for determination of density of microbial cells suspension (DENSILAMETER II TYPE: DENSI-2). Statistical processing of the results was made using the pack of Microsoft Excel programs.

\section{Results and discussion}

Our results have shown that the minimum inhibitory concentration (MIC) of enrofloxacin (control) after 22 hours of incubation was $6.25 \mu \mathrm{g} / \mathrm{ml}$, and was two times higher than MIC of the complex of enrofloxacin with GluLa-DPG-PEG600. MIC of the complex of enrofloxacin with GluLa-DPGPEG600 was $3.12 \mu \mathrm{g} / \mathrm{ml}$. Moreover, the average values of the number of microbial cells (MK) in experimental samples were lower than in the control samples in 5.5 times which means higher antibacterial activity of the complex of enrofloxacin with nanopolymer compared to enrofloxacin (table 1). 
Antibacterial activity of the complex of enrofloxacin with GluLa-DPG-PEG600 after 22 hours of incubation $(M \pm m, n=3)$

\begin{tabular}{|c|c|c|c|}
\hline \multirow{2}{*}{ no. } & $\begin{array}{c}\text { Antibiotic concentration, } \\
\mu \mathrm{g} / \mathrm{ml}\end{array}$ & \multicolumn{2}{|c|}{ The amount of bacterial cells, MF } \\
\cline { 2 - 4 } & 50 & Enrofloxacin & Complex of enrofloxacin with GluLa-DPG-PEG600 \\
\hline 1 & 25 & 0 & 0 \\
\hline 2 & 12.5 & 0 & 0 \\
\hline 3 & 6.25 & 0 & 0 \\
\hline 4 & 3.12 & 0 & $0.03 \pm 0.03$ \\
\hline 5 & 1.56 & $0.06 \pm 0.03$ & $0.1 \pm 0 * * *$ \\
\hline 6 & 0.78 & $0.2 \pm 0$ & $0.26 \pm 0.03^{* * *}$ \\
\hline 7 & 0.39 & $1.7 \pm 0.05$ & $0.36 \pm 0.03^{* * *}$ \\
\hline 8 & 0.19 & $2.33 \pm 0.08$ & $4.33 \pm 0.06$ \\
\hline 9 & 0 & $4.53 \pm 0.08$ & \\
\hline 10 & & & \\
\hline
\end{tabular}

Note: in this and the next table $* * *-\mathrm{P}<0.001$

After 44 hours of incubation, MIC of enrofloxacin was $6.25 \mu \mathrm{g} / \mathrm{ml}$ and was the same as MIC of the complex of enrofloxacin with GluLaDPG-PEG600. However, the average values of the number of microbial cells (MK) in experimental samples were lower than in the control samples in 6 times which means higher antibacterial activity of the complex of enrofloxacin with nanopolymer compared to enrofloxacin (table 2).

Higher antibacterial activity of the complex of enrofloxacin with nanopolymer GluLa-DPGPEG600 compared to enrofloxacin is probably the result of the presence of polyethylene glycol in nanopolymer molecule. It is known that polyethylene glycol can cause membranes permeabilization by increasing the number of pores which probably can increase cell absorption of enrofloxacin in complex with nanopolymer [2].
In addition, scientific article described that PEGylated ofloxacin nanoparticles render strong antibacterial activity against many clinically important human pathogens, which is also explained that polyethylene glycol has the ability to bind DNA and probably enhance the antibiotic activity of complex of enrofloxacin with GluLa-DPGPEG600 by increasing the affinity of enrofloxacin to DNA [9]. Enrofloxacin belongs to fluoroquinolone class of antibiotics that are effective against both Gram-negative and Gram-positive bacteria, acts via violate DNA synthesis by inhibiting DNA gyrase and topoisomerase II enzymes. Higher antibacterial activity of complex of enrofloxacin with GluLa-DPG-PEG600 probably can be also the result of the presence of lauric acid that covalently binded to glutamic acid in molecule of nanopolymer GluLa-DPG-PEG600. It is described in litera-

\section{Antibacterial activity of the complex of enrofloxacin with GluLa-DPG-PEG600} after 44 hours of incubation $(M \pm m, n=3)$

\begin{tabular}{|c|c|c|c|}
\hline \multirow{2}{*}{ no. } & $\begin{array}{c}\text { Antibiotic concentration, } \\
\mu \mathrm{g} / \mathrm{ml}\end{array}$ & \multicolumn{2}{|c|}{ The amount of bacterial cells (MF) } \\
\cline { 2 - 4 } & 50 & Enrofloxacin & Complex of enrofloxacin with GluLa-DPG-PEG600 \\
\hline 1 & 25 & 0 & 0 \\
\hline 2 & 12.5 & 0 & 0 \\
\hline 3 & 6.25 & 0 & 0 \\
\hline 4 & 3.12 & 0 & $0.03 \pm 0.03$ \\
\hline 5 & 1.56 & $0.06 \pm 0.03$ & $0.1 \pm 0^{* * *}$ \\
\hline 6 & 0.78 & $2.2 \pm 0.05$ & $0.36 \pm 0.03^{* * *}$ \\
\hline 7 & 0.39 & $5.16 \pm 0.12$ & $0.46 \pm 0.03^{* * *}$ \\
\hline 8 & 0.19 & $5.7 \pm 0.11$ & $0.7 \pm 0.05^{* * *}$ \\
\hline 9 & 0 & $7.23 \pm 0.12$ & $7.13 \pm 0.08$ \\
\hline 10 & & & \\
\hline
\end{tabular}


ture that polymer of lauric acid and poly-l-lysine has an antibiotic properties which is the cause of amphiphilic properties of polymer which cause the destabilization of membranes, both gram-positive and gram-negative bacteria by interacting with the lipid layer of bacterial cells [11].

\section{Conclusions}

The results of our study shows a higher antibacterial activity of the complex of enrofloxacin with nanopolymer GluLa-DPG-PEG600 compared to enrofloxacin. The reason of the higher, compared to enrofloxacin, antibacterial activity of complex of enrofloxacin with nanopolymer can be the presence of polyethylene glycol and probably lauric acid in nanopolymer molecule.

Perspectives for further research. In further research we will study the influence of the studied complex of enrofloxacin with nanopolymer GluLa-DPG-PEG600 on bovine sperm cells and its influence on rat body. In particular, we will research the toxicity of the complex and its influence on the structural and functional state of rats liver and kidneys.

1. Akira S. Innate immunity and adjuvants. Biological Science, 2011, vol. 366 (1579), pp. 2748-2755.

2. Chakrabarty B., Ghoshal A. K., Purkait M. K. Effect of molecular weight of PEG on membrane morphology and transport properties. Journal of Membrane Science, 2008, vol. 309, pp. 209-221.

3. Chekh B. O., Ferens M. V., Martyn Y. V., Ostapiv D. D., Vlizlo V. V. Functional and structural state of rats' kidneys and liver under the influence of nano-polymer based on pseudopolyamino acids. The Animal Biology, 2016, vol. 18 (3), pp. 107-113. DOI: 10.15407/animbiol18.03.107.

4. Chekh B. O., Ferens M. V., Martyn Y. V., Ostapiv D. D., Vlizlo V. V. GluLa-DPG-PEG600 nanopolymer binds proteins and spreads to rats' organs and tissues. Studia Biologica, 2016, vol. 10, no. 3-4, pp. 17-24.

5. Chekh B., Ferens M., Susol N., Varvarenko S., Ostapiv D., Vlizlo V. Nanopolymer GluLa-DPGPEG600-F Can Penetrate into Cells and Deposite in Rats Body. Scientific herald of the Lesia Ukrainka Eastern European National University, 2016, vol. 12, pp. $138-142$.

6. Hubbel J. A. Bioactive biomaterials. Current Opinion in Biotechnology, 1999, vol. 10, 129 p.

7. Kovalev V. F., Volkov I. B., Violin B. V. Antibiotics, sulfanilamides and nitrofurans in veterinary medicine. Agropromizdat, 1988, 223 p. (in Russian)

8. Lee K. Y., Mooney D. J. Hydrogels for Tissue Engineering. Chemical Reviews, 2001, vol. 101 (7), pp. 1869-1879.

9. Marslin G., Revina A. M., Khandelwal V. K. M., Balakumar K., Sheeba C. J., Franklin G. PEGylated ofloxacin nanoparticles render strong antibacterial activityagainst many clinically important human pathogens. Colloids and Surfaces B: Biointerfaces, 2015, vol. 132, pp. 62-70.

10. Varvarenko S. M., Figurka N. V, Samaryk V. Y., Voronov A. S., Tarnavachyk I. T., Nosova N. G., Dron I. A., Taras R. S., Voronov S. A. Synthesis and surface-active properties of new polyester - pseudopolyamino acids based on natural two-base amino acids. Reports of the National Academy of Sciences of Ukraine, 2013, vol. 5, pp. 131-139. (in Ukrainian) 11. Vidal L., Thuault V., Mangas A., Coveñas R., Thienpont A., Geffard M. Lauryl-poly-L-lysine: A New Antimicrobial Agent? Journal of Amino Acids, 2014, pp. 1-9. 